\title{
Pandemic, SDGs, and CSR: Case Study of Indonesia
}

\author{
Sudharto P Hadi ${ }^{1,2 *}$, Mohd Hairy Ibrahim ${ }^{3}$, Bulan Prabawani ${ }^{1}$, Sri Suryoko ${ }^{1}$ \\ ${ }^{1}$ Department of Business Administration, Faculty of Social and Political Sciences, Diponegoro \\ University, Jalan Prof. Soedarto, SH Tembalang, Semarang, Indonesia \\ ${ }^{2}$ Program of Environmental Studies, Postgraduate Program, Diponegoro University, Jalan Imam \\ Bardjo, SH Pleburan, Semarang, Indonesia \\ ${ }^{3}$ Faculty of Human Sciences, Universiti Pendidikan Sultan Idris, Perak Malaysia
}

\begin{abstract}
Pandemic covid-19 does not only threat lives and health of people but also hit economic, social, and well-being. Large scale social restriction (PSBB) paralyze all economic activities, in turn, causing unemployment and escalating the number of poor people. Indonesian government provide direct social assistance and other measures to ease the burden of impacted people. Pandemic covid-19 also threats the target of achieving SDGs specifically dealing with pillar 1 (no poverty) and pillar 2 (zero hunger). Through CSR, corporates have important role in dealing with pandemic covid-19 at the stage of emergency and rehabilitation. This paper observed two corporates, holder of Gold Proper ranking, in responding pandemic covid-19 at their areas. This is a descriptive research in which the content analysis, literature review, and webinar are employed to collect the data. The data gathered analysed qualitatively. The CSR adopted by two corporates do not only deal with emergency and rehabilitation stages but also empower people to produce products needed during the pandemic covid-19.
\end{abstract}

Keywords: pandemic covid-19; sdgs; csr

\section{Introduction}

All countries in the world including Indonesia have been struggling to deal with pandemic covid-19 [13]. Indonesia was relatively late in responding and anticipating pandemic covid19. When the outbreak firstly occurred in Wuhan, China, at the end of December 2019 and other countries have announced the number of victim with variety of action to deal with, Indonesia did not take any action until March 2, 2020 when two persons stated as infected covid-19. There was no travel restriction, referred health centre, lack of diagnosis and scientific survey, also nor data transparency [2]. As of May 16, 2020 total number of infections nationwide was 17,025, bringing the death toll to 1,089 and making this country as most victim in Asia. Pandemic covid-19 does not only threat lives and severely affect

\footnotetext{
${ }^{*}$ Corresponding author : $\underline{\text { sudhartophadi@yahoo.co.id }}$
} 
human health but also hit economic, social and wellbeing [2]. It is predicted that economic growth will slow down until minus 0.3 percent making the worst economic crisis in the two last decade. The number of people will lose their job reach to 2.9 until 5.2 million people and about 2.8 million people will be laid off. Unemployment will be escalated to be 7.5 percent. COVID-19 will exacerbate inequalities. To limit the spread of the virus, some provincial, city and regency governments promoted PSBB (large scale social restriction) and travel restrictions. In dealing with poor and vulnerability impacted people, the government provide social safety net and direct social assistance. This paper observed how pandemic covid-19 affected the achievement of SDGs (sustainable development goals) and how private sector through CSR contributed to deal with the impact of covid-19.

\section{Literature review}

Historian Yuval Hariri said that the present pandemic is the worst crisis humankind have faced at least in the last 100 years [5, 7]. No person, institution or country has had the experience of handling a pandemic of this magnitude. Consequently, no reference is available for creating simulations, designing scenarios, and developing mitigation strategies. It is difficult to run simulations, because there are still too many assumptions to date. The scale of infection is too broad, while the dynamics of the pandemic is still developing. The policies taken by the government are centralized and top down in character. [5, 8]. Indonesian government prepare and distribute social assistance in the form of basic necessities. Funds of Rp105 trillion have already been prepared. Social direct assistance is Rp600,000. - per person per month for three months: April, May, June. Quick response with lack of coordination frequently utilize inaccuracy data, consequently many needy people were not reached by direct social assistance. According to spokesman of covid-19 management, on webinar with National Research Council on April 29, 2020 [10, 11], pandemic covid-19 is communicable disease need to be dealt with community approach. People have to be treated as object and subject meaning that they have to be in front-line in dealing with covid-19 by behaving clean, healthy, discipline, orderly, always wearing mask, avoid crowding. At the post of covid-19 pandemic, most humans will still be alive but in a different way not only health, but also economically, politically, and culturally [7].

Sustainable Development Goals (SDGs), is commitment of heads of country across the world to combat poverty and to create good environment for development. SDGs is continuation of MDGs (Millennium Development Goals). The pillars related to the impact of pandemic covid-19 include (1) no poverty: end poverty in all its forms everywhere (2) zero hunger; end hunger, achieve food security and improve nutrition and promote sustainable agriculture (3) good health and well-being: ensure healthy lives and promote well-being for all at all ages (6) clean and water and sanitation; ensure availability and sustainable management of water and sanitation for all (8) decent work and economic growth: promote sustained, inclusive and sustainable economic growth; full and productive employment and decent work for all. [9, 12]. When MDGs ended in 2015, 35 million people were in below poverty line, proportion of people have the access to clean water and sanitation were not increased significantly, more than 30 percent people live in urban area and 50 percent people live in rural area did not have access to clean water, mortality rate was 307 per 100,000, the highest in Southeast Asia, 95 percent children entered to primary school and only 81 percent continued to junior high school, and between 1997-2000, Indonesia lose 3.5 million hectare per year. To accelerate the achievement of SDGs, the Indonesian government issued Presidential Decree 59 of 2017 on the execution of SDGs. One target to be achieved is that, at the year of 2030 to reduce at least half of male, female and children of all ages proportion at poverty at all dimension parallel with national definition [6]. Mid-term development plan (RPJM) 2015-2019 determined a target that in 2019, decreased number of 
poverty from 11.13 percent in 2015 to be $7-8$ percent in 2019 . With pandemic covid-19, the target is difficult to realize.

Article 15 of Presidential Decree stipulates that to achieve sustainable development goals, governor, mayor and head of regency involve mass organization, philanthropic, private sector, academician and other relevant parties. With regard to private sector specifically state owned company, they are obliged to allocate sum of money for CSR (corporate social responsibility) as stipulated by Act no 40 of 2007 on limited corporate saying that corporate which its business field on and related to natural resource is obliged to conduct corporate social responsibility. Ministry of State Owned Company followed up this Act by promulgating Ministerial Decree no 09 of 2015 determines that corporates under state owned company must allocate fund for CSR maximum 4 percent of gross profit.

\section{Research Method}

This is a descriptive analysis. The scope of research includes the type of CSR adopted by two industries during the pandemic and the impacts to beneficiaries. The data collection techniques consist of content analysis, webinar and literature review specifically related to sustainability reports. The case studies involved PT PJB (Power Generation of Java-Bali) and PT PKT (East Kalimantan Fertilizer Factory), two Gold ranking of Proper (business performance rating on environment) since 2017 to 2019.

\section{Result and Discussion}

The following corporates, they are PT PJB and PT PKT are the holder of Gold ranking of Proper (business performance rating on environment) consecutively since 2017, 2018, 2019. PT PJB (PT Pembangkitan Jawa Bali or Power Generation of Java-Bali) is corporate under PLN (Electric State owned Company) with headquarter in Surabaya, East Java has been taking action dealing with Covid-19 for surrounding community at its 14 units power generation across Indonesia. Its action is part of CSR consisting of the following activities. (1) providing 5,000 fabrics to nine local tailors produced as masks sold to PJB's workers and public. With this activity, they earn Rp25 million. (2) facilitating local people to process healthy food and drink made from Kelor (traditional leaves) to improve the immunity. There are 13 households processed Kelor as juice and earn Rp55.3 million while other households benefit from processing Kelor as healthy food and enjoy Rp20 million. PT PJB also provide 2760 portable wasteful. [4]. Another company takes action for covid-19 is P.T PKT (fertilizer factory) base in Bontang, East Kalimantan providing: (1) medical instrument for hospital, office and community (2) nine basic foods for medical team and community. In addition, PT PKT also facilitates 71 local screen printer and disable children to produce masks sold to PT PKT workers and public. PT PKT also facilitate fostered partner to produce dried cake. The budget allocated for dealing with covid-19 is Rp2.8 million. [11]

The type of CSR adopted during pandemic covid-19 by two corporates is not only in the form of charity namely basic need (sembako) and infrastructure (medical instrument) but also community empowerment by facilitating local people to produce mask, food and drink needed during the pandemic covid-19. Both corporates also utilize the existing community groups have been facilitated for regular CSR. In terms of sustainable development, these community empowerment programs by corporations are manifestation of a six level of a sustaining corporation of human sustainability [1]. Relevant to Harari [7], corporate sustainability (CS) is deemed as a solution to obtain social, environmental, and economic goals [3]. 


\section{Conclusion and recommendation}

Private company as one stakeholder in helping alleviate poverty and achieve the target of SDGs has important role to ease the burden of people facing pandemic covid-19. Their assistance not only deal with emergency response such as providing basic need and medical instruments but also empowering people to produce products needed during the pandemic covid-19. The profit earned is meaningful in easing the burden of affected people. The products are still prospective because they are still required during the new normal when people must behave clean and healthy on daily live. The coordination with the local government to determine the beneficiaries is required to get proper target of affected people. Variety of products produced by facilitated community groups need to extend including hand sanitizer with local material. Another form of community development need to be developed is organizing local people in preventing the spread of various.

\section{References}

1. Benn, S., Dunphy, D., \& Griffiths, A. Enabling Change for Corporate Sustainability: An Integrated Perspective. Australasian Journal of Environmental Management, 13(3), 156-165 (2006)

2. Djalante, R., Lassa, J., Setiamarga, D., Sudjatna, A., Indrawan, M., Haryanto, B., ... Warsilah, H. Review and analysis of current responses to COVID-19 in Indonesia Period of January to March 2020 _ Elsevier Enhanced Reader.pdf. Progress in Disaster Science, 1(6), 1-9 (2020)

3. Ikram, M., Zhou, P., Shah, S. A. A., \& Liu, G. Q. Do environmental management systems help improve corporate sustainable development? Evidence from manufacturing companies in Pakistan. Journal of Cleaner Production, 226, 628-641 (2019)

4. Krisdyatmiko. Kemitraan dalam Implementasi SDGs/TPB untuk Kesejahteraan. Workshop Pengelolaan \& Perlindungan Lingkungan Hidup yang Berkelanjutan PHE WMO. 30 Mei 2018, Surabaya, Indonesia (2018)

5. Prasentyoko, A. 2020. Pandemic, Recession and Mitigation. Kompas, March, 31, 2020, Daily (2020)

6. Peraturan Presiden 59/2017, Pelaksanaan Pencapaian Tujuan Pembangunan Berkelanjutan (2017)

7. M\&A News. Yuval Noah Harari: The world after coronavirus. Financial Times,(April), 1-14 (2020)

8. Nugroho, Yanuar. 2020. Vision After Pandemic. Kompas, May 15, 2020, Daily (2020)

9. Salim, Emil. 2018. Tujuan Pembangunan Berkelanjutan. Kompas, 2 July 2018, Daily (2018)

10. Supriyanto, Hery., Keterlibatan CSR PT PJB dalam Penanggulangan Covid-19. Presented at Webinar CSR untuk Penanganan Krisis Covid-19. Organized by Gadjahmada University, April, 29,2020, Yogyakarta, Indonesia (2020)

11. Susilo and Husaeni, Fakhri. Kontribusi PT Pupuk Kalimantan Timur Dalam Pencegahan \& Penanganan Pandemik Covid-19. Presented at Webinar CSR untuk Penanganan Krisis Covid-19. Organized by Gadjahmada University, April 29, 2020 , Yogyakarta, Indonesia (2020)

12. United Nations. Transforming Our World: The 2030 Agenda for Sustainable Development. A New Era in Global Health (2018) 
13. World Health Organization. Coronavirus Disease 2019. In A \& A Practice (Vol. 14) (2020) 